\title{
Significance of Social Vision in the Process of Reshaping Islamic Education
}

\section{Yousef Rahath*}

\begin{abstract}
The purpose of this paper is to discuss the importance of social vision of Islam in formulating Islamic education. It has been assumed that due to neglecting the social dimension of Islam, most of the contemporary Islamic educational institutions are incapable of enabling the younger generation to look at the historical context of their lived reality more critically. Consequently, most of the Muslims are not bothered about several concrete human social problems such as inequality, economic exploitation and fragmentation of the community into different classes and groups. To solve this issue, the article suggests incorporation of the social dimension of Islam in the educational curricula. Since the Quran portrays human being as a social being by highlighting his various responsibilities in this world, one of the guiding principles of Islamic education should be to make Muslims capable of understanding the world for making it more just and better. Only then would Muslims be able to make a link between knowledge and action.
\end{abstract}

Key Words: Social Vision, Active Spirituality, Social Responsibility, Private and Social Being

\section{Introduction}

Social vision is the set of fundamental ideas presented by any ideology or religion or school of thought to allow its followers to work together as a unit to achieve social goals. Concepts that define the obligation of a society including the role of individuals in that society, the collective responsibility of individuals, the place of individuals within that society are essential parts of social vision. In that sense, social vision becomes a guiding principle that shapes social institutions and infra structures of

* Assistant Professor, Kulliyyah of Education, International Islamic University Malaysia. Email: yusufrahath@iium.edu.my 
a society. Hence, social vision that a religion or a philosophy offers has a great impact on determining an educational system. It is imperative because the principles that guide the theory and the practice of education are in great measure derived from the social vision a religion or a philosophy has to offer to the world (Kazmi 2010). Therefore as far as Islamic education is concerned, how Islam visualizes the social world is imperative in shaping the content and principles of Islamic education. The content and principle of Islamic education would not have a social dimension, if Islam does not have an active social vision that suggests a concrete social involvement. In such a situation it would not be the concern of Islamic education to make students responsible for their social world. Besides this, issues such as social justice, collective salvation, individual freedom and equality would become trivial. Therefore, to justify a social oriented-emancipatory Islamic educational approach we need to establish the active social vision of Islam.

\section{Islam and Active Social Vision}

Among all the major religions of the world, one of the significant aspects of Islam is that it offers an active social vision that relates the concrete material world with the other world. Islamic spirituality is active and concrete. In other words, there is no such a thing as passive or abstract spirituality in Islam. Passive or abstract spirituality is something that confines spirituality in rituals and customs. In such spirituality, efforts to address concrete human problems would not be recognised as a way for salvation. Moreover, since the only possible way for salvation is the complete involvement in a world of silent contemplation disregarding all kinds of human issues, rituals and sacraments would be maintained perfectly in a religion which emphasises passive spirituality. However, a religion with active spirituality should have a different approach. For a religion that emphasises active spirituality, concrete social involvement would be a vital ethical and spiritual issue. The issue of making the followers responsible for their social world would be considered to be a religious responsibility and thus there would be a passion to engage in and on the world in order to attain social goals. In other words, concrete human issues and worldly matters would definitely be a greater concern for a religion that has an active spirituality. 
In fact, Islam has never put forth a notion of passive spirituality so as to be reduced to only heavenly affairs while neglecting earthly issues. But, it has always been a way of life that guided people in shaping their life in this world in accordance with the divine light. Islam relates each and every human activity with the other world by taking this world as a platform for human articulation of divine truth. Instead of asking people to give up this world for the anticipated better life in the other world, Islam asks them to be active in this world, for higher and better rewards in the other world. "But seek, with that (wealth) which Allah has bestowed on you, the home of the Hereafter, and forget not your portion of lawful enjoyment in this world; and do good as Allah has been good to you, and seek not mischief in the land." (al-Quran 28:77). This means, unlike other religions, Islam has given equal importance to this world as well as the other world. It might be correct to say that if this world does not exist, there will not be a necessity for the existence of the other world.

One of the important characteristics of active spirituality of Islam is that it relates human being's personal life with social life and the creator as well. In Islam there is no isolated vertical relationship between a person and God. It is simultaneously vertical and horizontal: a vertical relationship with Allah and horizontal with other living beings. It is not possible to maintain a vertical relationship with Allah disregarding the horizontal relationship with other living beings. Prophet said: "God shows his mercy to those who are merciful. Have compassion to creatures on earth so that those in heaven may have mercy upon you" (al-Tirmidhi, Muhammad ibn Isa Abu Anas Isa, nd, p. 323 Vol 4). This means that if a person is looking for mercy from Allah he must be merciful to all other living beings. To be specific, the best way to get Allah's mercy is to be merciful to others. "Certainly Allah helps His servant, as long as he helps his brother" (Muslim, Sahih Muslim, p. 71 Vol 8)! In several places, the Qur'an has emphasised the significance of horizontal relationship with other living beings. The same idea is mentioned in the Qur'an when the Qur'an talks about birr (virtue). The Qur'an says:

It is no virtue that you turn your faces towards the east or the west, but virtue is that one should sincerely believe in Allah and the Last Day and the Angels and the Book and the Prophets and, out of His love, spend of one's own 
account wealth for relatives and orphans, for the needy and the wayfarer, for beggars and for the ransom of slaves, and establish the Salāt and pay the Zakāt. And the virtuous are those who keep their pledges when they make them and show fortitude in hardships and adversity and in the struggle between the Truth and falsehood; such are the truthful people and such are the pious.(al-Baqarah: 177)

According to Islam, even worship should be considered as a worthless action, if it is not accompanied by concern for the well-being of society. The Qur'an states: "Have you seen him who denies the recompense? It is he who repulses the orphan, and urges not the feeding of the poor." (al-Mà' 'ùn: 1-3). Allah says: "But he has not attempted to pass on to the path that is steep. And what will make you know the path that is steep? Freeing a slave. Or giving food in a day of hunger.To an orphan near of kin. Or to a poor out of misery" (Al-Qur'an, al-Balad: 11-16). We can see several expressions of such of sentiments in the Qur'an. This is, of course, the distinguishing feature of active social vision of Islam that suggests a philosophy of social involvement. Since individual salvation is not possible without being involved in the social world, every Muslim is responsible for, and to his social world. Hence, Muslims should engage in this world in order to create a better social condition that offers a better life to everybody. This is the important aspect of the social dimension of Islam.

The Qur'anic theme of social involvement is best encapsulated in the Islamic notion of amr bi al-ma 'arüf and nahy 'an al-munkar. It is not an isolated theme, but a theme the Qur'an emphasises throughout. The Holy Qur'an declares: "And from among you there must be a party who invite people to all that is good and enjoin the doing of all that is right and forbid the doing of all that is wrong. It is they who will attain true success." (Al-Qur'an, alu Imran: 104). To have a better society is a condition for collective salvation because the increasing presence of social ills will prevent the salvation of a large number of people by making them collaborators in those ills. If Islam's primary concern is individual salvation, why would Allah ask people to engage in this world to prevent wrongdoings?

Prophet Mohammed's (Peace Be Upon Him) coming down from the cave Hirā' can also be taken as a powerful symbol representing the significance of active participation in the world (Kazmi, 2011). The 
specific nature of all prophets was their total involvement in the world. Prophets were not priests who spend their time upon rituals and $d u$ 'as only; prophets were not people who kept silent toward social issues and injustice. They were not the so-called 'spiritual leaders', talking about things that are not helpful in worldly life and keeping themselves away from the social realities. But they were people who lived among the people and stood for their welfare. They never tried to keep a distance from the concrete human social problems. Prophet Shuaib (P.B.U.H) is one of the examples. When he started his $d a$ 'wa activities he was much exercised by the rampant exploitation and cheating around him. What was his response? Did he keep silent? Did he try to adjust with the social illnesses? No, he rebuked the people and forbade them from engaging in such activities as well as shirk. He invited people to lāilāhaillallāh. But, for him lāilāhaillallāh had two dimensions; one is divine; to worship Allah, the other is earthly; to abandon exploitation. Qur'an indicates this through the debates, which took place between Shu'aib (P.B.U.H) and his people. They asked him: "O Shu'aib! Does thy (religion of) prayer command thee that we leave off the worship which our fathers practiced, or that we leave off doing what we like with our property?!'(Al-Qur'an 11:87).

When the Qur'an describes characteristics of the last prophet, it says: "He releases them from their heavy burdens and from the chains that were upon them"(al-Qur'an 7:157). Prophets were individuals who transformed history and societies by uprooting the unjust social system that protected the interests of the rich and the powerful. It was divine will to change the history and emancipate the oppressed through the hands of human being. The Qur'an unfolds this fact in its description of the conflict between the Egyptian tyrant, Pharaoh, and the prophet Musa: "And we wished to do favour to those who were weak and oppressed in the land, and to make them rulers and to make them the inheritors and facilitate them in the land, and We let Fira' un and Haman and their hosts receive from them that which they feared" $(28: 5,6)$. It is the responsibility of Muslims to rise against any kind of injustice that prevails in a society. The Holy Qur'an has shown how important justice is when it declares: "Believers! Be upright bearers of witness for Allah, and do not let the enmity of any people move you to deviate from justice. Act justly, that is nearer to God-fearing (Qur'an 5:8). The prophet's saying, "And he who is killed while attempting to remedy injustice, is a martyr" (Qutb, 2000 
p. 33) also conveys the same message. Islamic notion of ' $a d l$ (justice) is another powerful concept that ensures collective salvation. Since Allah has given everybody the opportunity to become khaliffah and has made everyone equal without making barriers between people, it is the basic requirement of this equality that social justice be maintained. In other words the absence of justice will prevent the salvation of a large number of people by denying them the opportunity to enjoy God given freedom and dignity.

According to the Holy Qur'an, the purpose of life on earth as ordained by Allah is to act in accordance with the principles given by Him so as to make a situation, which is better than ever before. Allah states "Who has created death and life, that He may test you which of you is best in deed"(al-Qur'an 67:2). The Qur'anic description of life and death as a means to persuade man to 'act' can also be considered to be another powerful example that envisages the philosophy of social involvement. It could be more interesting to see that Allah has mentioned death along with life to underline the importance of action. It is not hard to visualize the relationship of life with action because the life is the dais where human action is staged on. But how is it possible to consider death as a platform for action? Since death denotes the closing phase of life, it would be difficult to envisage the relevance of death in relation to action. One plausible construal is that death persuades human action. Then, it can be explained that the awareness of the fact about one's end or finitude must pressurize a person to take a stand in all aspects of his life when he engages in this world. If there is no pressure or awareness of the time span which has been given to a person, he would not take life seriously whereasonly the serious approach towards the life can create a situation where human beings try to fulfil the responsibilities as early as possible.

\section{Social Vision and Islamic Education: A Historical Analysis}

What has been mentioned above clearly points out the distinguished features of Islamic social vision. The Islamic educational curricula must also be derived from this social vision. Deriving an educational philosophy from the social vision of Islam is imperative. Otherwise, education would end up without having a corresponding relationship between knowledge and social engagement. It was a historical fact that even though Muslim Intellectuals have shown greater interest in 
the development of the Islamic educational system during the colonial era, especially in the later $19^{\text {th }}$ century, much significant conscious effort was not given to the social vision of Islam. It could be said that during the $19^{\text {th }}$ century Islamic educational discourse was conflicted by the challenges of two divergent views which shaped its perception of education in a number of fundamental ways (Sidiqi, 1982). On one hand, the elite and ruling class considered it to be of the highest priority to introduce the western secular educational policy, which aims at technological innovation, progress and prosperity. On the other hand, it was the common perception of ordinary Muslims that the adoption of modern secular education to the Muslim nations would ruin everything known as 'Islamic' (Kallin, 2008). Although these two divergent approaches have been presented as anti-thesis of each other, the ultimate consequence of both approaches was the same - perception of Islam as an asocial and apolitical religion. In other words, educated Muslim intellectuals who stood for adopting western nationalism; secularism and culture never highlighted the significance of social vision of Islam. For them replication of the ideologies that shaped the western sociopolitical structure was more important than anything else because they were of the view that the major reason for European development was that Europe dared to give up the Christian religion to have progress and prosperity (Hyness, 2006). In that sense, the uncritical acceptance of secularism and the western theories of development directly or indirectly created a situation in which, Islam's ability to face the concrete social problems was questioned (Qutb M, 1977). On the other hand, the other approach that was widely celebrated by the traditional religious people was not better than this. Even though they had a strong feeling of enmity towards the secularisation process, most of the traditional Muslim scholars adopted a literal religious approach, having a narrow perception of religion so that the concept of 'what is to be religious' became an abstract notion that does not seek any particular type of human action in order to bring a positive change in this world. The focus was on the life hereafter undermining the importance of this world. The major concern was how to maintain ritual elements of religion without a concrete social involvement. Considering this fact, it can be argued that during the colonial age not only extreme secularism, but the literal religiosity also played the same role in presenting Islam only as a means to decorate the spiritual life, but not a solution to the concrete human problems. In other words both of the trends had significant role in 
uprooting the social dimension of Islam from the educational setting of post- colonial Muslim nations.

But, as far as $21^{\text {st }}$ century Muslim educational discourse is concerned, it might be wrong to argue that the lack of Muslim effort to relate education with the social vision of Islam is because of the narrow understanding of Islam as a religion of a 'set of rituals and customs'. This can be said because the modern Islamic religious landscape has undergone tremendous change since the emergence of Islamic revivalism. Revivalist scholars such as Abul A'la Mawdūdī (1903-1979), Sayyid Quțub (1906-1966), 'Alī Sharīatī (1933-1977) and Ḥasan al-Bannā'(1906-1949), made fabulous efforts to create awareness among the Muslims of the significance of social involvement and social change. They believed that Muslims could only successfully respond to the encroachment of western civilization through a reformed Islamic system within which the socio-political dimension of Islam is recognized. The major idea that was propagated by the revivalist scholars was that 'Islam is a way of life that does not separate spirituality from the worldly life'. According to them, Islam has the ability to be translated in any particular context so that it could be decoded in modern context. It can be argued that the revivalist scholars' attempt has succeeded in convincing Muslim society of the significance of the social vision of Islam. Eventually, the common perception of Islam as merely a ritualistic religion was removed and it has been agreed by the majority of Muslims that Islam has a central role in the nation building process of each and every Muslim society.

When later Muslim educational thinkers such as al-Faruqi and al Attas, tried to develop an appealing Islamic educational philosophy called Islamization of Knowledge (IOK), it was very clear that, akin to the revivalist thought, they recognised the socio-political significance of Islam and took a firm stand against the secularisation process. Obviously, the Islamization of Knowledge project was an effort to solve the crisis of religion in modernity. All the scholars who supported Islamization of Knowledge explicitly stated that there was confusion among Muslims because of the dual system of education, one secular or modern, and the other, religious or traditional (al-Alwani, 1995; Ashraf, 1985; Haneef, 2005). Therefore, what the Islamization movement claimed as "necessary, is the emergence of a third group that 
are acquainted with their own traditions but are willing to acquire any wisdom that modern civilization can offer" (Husain \& Ashraf 1979, p.15). For initiators of the IOK project, to Islamize knowledge, meant to give equal importance to religious and worldly knowledge in order to overcome the dichotomy between religious knowledge and modern sciences. In that sense 'Islamization of knowledge' as 'integration' theoretically rejects the perception of religion as apolitical. In that sense, the emergence of 'Islamization of Knowledge' can be considered further development of Muslim efforts to address the issue of secularism and educational dualism by recognising the social vision of Islam. This new development in the Islamic educational discourse contributed an enormous opportunity to make people aware of the social vision of Islam. However, despite the fact that the social vision of Islam has been acknowledged by the contemporary Islamic educational discourse, as far as the practical dimension is concerned, Muslim educational practice still continues the same system that does not contextualise the social vision of Islam.

\section{Social Role of Contemporary Islamic Education}

It should be noted that the enormous attention paid by Islamic scholars to synthesize modern knowledge with traditional knowledge has received a wide acceptance. However, when we look at the socio-political scenario of the Muslim world, we can see the complete neglect of the social vision of Islam and hence, lack of social responsibility. Neglect of the social vision of Islam here means the tendency to perceive Islam as asocial and ahistorical religion, and the lack of social responsibility refers to the negligence of social involvement. In other words, in a practical sense, the majority of Muslim educational establishments do not show much interest in making the new generation of Muslims responsible for their social world. When Muslim countries developed post independent educational policy, most of the Muslim countries have agreed that Muslim nations should implement modern education without being alienated from the Islamic culture. Thus, the will of the Muslim countries to participate in the modernisation process through an advanced educational programme can be seen everywhere. And, almost all Muslim nations had conceded that the nation's decision to move towards modernisation meant that the system of education had to be remoulded so that it would be able to provide sufficient human resources to meet the demands of the economy. Nonetheless, apart from 
the economic goal of education, Muslim educators were not concerned to enquire and formulate the social aims of education reflecting the social vision of Islam. Hardly any of them discussed what should be the form of society that would be constituted through Islamic education. In other words, there had not been sufficient deliberate attempts to relate educational curricula to the concrete social issues of the world. Issues such as poverty, inequality, economic exploitation, environmental deterioration, urbanisation, and neo-colonisation have not been given considerable importance by the educational curricula. Consequently, graduates of most of the Islamic institutions don't have substantial knowledge to face the challenges of these concrete issues. It can be said that they are not even able to see the unjust nature of most of the issues.

The major reason for the neglect might be that Islamic educators have failed to perceive Islamic education from the perspective of the Islamic social vision. Consequently, the notion of what Islamic education is has been significantly narrowed down, making it to be perceived as something that deals with only abstract terms of spirituality rather than concrete human issues. Muslim educators' effort to reproduce some Arabic terminologies without critically reflecting on their consistency with Islamic social vision is an example. In doing so, they are more concerned with how to translate a given Qur'anic term or phrase to correspond to modern educational terminologies rather than making concrete and substantial suggestions regarding Islamic education. Muslim scholarship's discourse to bring the notion of khaliffahin the educational debate underlines this argument. Most of these debates focused on explaining the notion of khali fah using a language of abstract religiosity in order to highlight the significance of goodness, piety and discipline in Islamic educational setting. It is very important to note that abstract concepts like good man, pious individual, disciplined personalities are not able to bring a drastic change in any educational setting. This is because even non-religious philosophies had discussed the significance of these qualities. When such philosophies expressed the role of educational institutions in developing human personality they never refuted the importance of ethical values. For most of the educational philosophies, these values are essential educational entities because otherwise the co-existence of human beings is not possible and it would also be difficult to maintain a social system without having these values. Thus Muslim scholars' explanation of the Qur'anic 
terminology ' $k$ haliffah' is nothing more than the imitation of the same idea that has been acknowledged by the other contemporary educational discourse. To be specific, Muslim scholarships' elaborate discussion of spiritual development; inculcation of morality and ethical dimension of personality so forth is only a replication of the existing discourse. In such a situation, what makes stark distinction between conventional educational system and the Islamic one remains vague and questionable. In other words, what would be the fruitful substantial change required by the notion of khalifah remains equivocal. Due to this nature of discourse, most of the contemporary Islamic educational institutes bear a narrow perception of religion so that the concept of "what is to be religious' becomes an abstract concept that does not seek any particular type of human action in order to bring a positive change in this world. The focus is on the life hereafter undermining the importance of this world. No consideration is given for the fact that both the worlds are parts of a continuous world.

\section{Towards an Alternative Strategy}

The description structured in the previous section, explicitly, points out that there is no concern for the social vision in most of the Islamic educational discourses. In contrast, the underlining assumption of the Quran about human beings and the social world necessitates making the social vision of Islam the core theme of educational debate. This scenario demands us to form a different educational setting introducing a new Islamic educational approach. In other words, in order to bring Islam into our concrete reality we must bring about a philosophy of Islamic education, which gives importance to the concrete existence of human beings.

The possible way to relate education with the social vision of Islam is to explain terminologies like khalifah in a way that makes social involvement imperative. Only then would Muslim scholarship be able to explain the purpose of education from a different perspective. Instead of limiting the meaning of terminologies like khalifah to highlight the moral and spiritual dimension of education, the same terminology can be employed to emphasise the social dimension of human beings. Since the intrinsic meaning of khalifah carries the social dimension of human life, the purpose of education can be understood in terms of preserving this nature by guiding people to conform to what they have been given 
by Allah, when He made them vicegerent of earth. This swing from limited spiritual facet of khalifah to the social component of the same terminology will make education an intellectual activity that requires concrete understanding of the human world in orders to attain social goals for which Islam stands. Since Allah has made human beings the vicegerent on earth by giving them freedom of choice and creativity, letting people actively participate in the social world becomes the core principle of an educational setting that recognises social vision of Islam.

It is worthy to be noted that social engagement is not possible if people don't have enough knowledge on how the world works. To be specific, involvement in concrete human issues necessitates better understanding of the world in which human beings live and have built their civilization. Therefore, an educational approach that recognises the active nature of the social vision of Islam should be designed to enable students to understand the world and find solutions to the social issues. And also to make students feel that there is something they can do, not only for their own life, but for others as well. Students must be taught the fact that the socio economic condition of each society is designed by none other than we human beings ourselves. In addition to this they must be continuously reminded that nothing is impossible with regards to the social world. It means the world around them is socially constructed and since it is socially constructed anybody who sacrifices for that cause can change it. However, at the same time, this argument does not refute the presence of something that is completely out of human control. More correctly, it does not refute the human destiny. Yes, there are situations that are essentially uncontrollable: we must die; we must suffer; we must get illness. Moreover, the situations to which we are born are beyond our control. Human beings' nationality, gender, colour and physical appearance are not decided by them; but by the creator. The acceptance of this destiny is the supreme and final idea of Islam. (Izetbegovic 1984, p.35) But as a result of this acceptance human beings should not be reduced through deprivation and subjugation to the point where their will to act is destroyed. That is the remarkable aspect of Islamic concept of destiny. The fact that Allah has stated that he will not change human situation if human beings do not take the responsibility of brining about the changes, supports this claim. "Verily, Allah will not change the condition of a people as long as they do not change themselves." ((al-Qura'n 13:11) 
People should be taught that since they live in a shared world in which everything is shared with billions of people; one should work for collective salvation. Our longings to attain heaven will not be achieved without recognising people who live around us. This approach marks a stark distinction from existing the educational paradigm in which education is treated as a means for individual-personal salvation: the purpose of education is to get a job or to possess a role in the social stratification. Once we highlight the social vision of Islam in the educational context, the purpose should become something else; to find a better way that offers everybody an opportunity to overcome the difficulties that they face.

\section{Conclusion}

What I have said so far is that social involvement becomes an educational issue once we perceive Islam as a religion with an active social vision. It means the formation of an educational approach for making students responsible for the social world is only possible once Muslims take Islam as a religion of active spirituality. In other words, how Muslims perceive Islam becomes vital in determining the Islamic educational system. Therefore, the socio-political nature of Islam should be given emphasis in order to highlight the social vision that Islam offers. Moreover, in order to contextualize active social vision of Islam to our educational practice, we must highlight the fact that the Qur'anic notion of khaliffah is not a private being but a social being. A private being is only concerned with his private or personal salvation. A social being, on the other hand, recognises that his private salvation is tied up with the salvation of other human beings. The world of a social being is a shared world and the heart of shared world is the triangular relationship between individual, Allah and other living beings. This means we should recognise the historical and social nature of human beings in order to perceive education as something more than an entity that offers private salvation. We need to become self-reflective in constructively analysing our own history and educational practices to ensure that we do not reproduce an educational system that is inconsistent with the social vision of Islam. To be specific, we should develop an educational project in which Islam is restored to its rightful place at the centre of societal thought and action. 


\section{References}

al-Attas, Sayyid Muhammad Naqib. (1978). Islam and Secularism. Kuala Lumpur: Muslim Youth Movement of Malaysia.

Ali, M. M. (1999). Reconstruction of Islamic Thought and Civilization:An Analytical Study of the Movement for the Islamization of Knowledge. The Islamic Quarterly : A Review of Islamic Culture , 21-36.

al-Tirmudi, Muhammad ibn Isa Abu Anas Isa. (nd). Al-Jāmi a Șah̄ịhu alSunnah. Beirute: Dār Ihyāu al-Turās al-Arabi.

El-Mokhtar, Mohamed. (1998). Islamic Education Between Tradition and Modernity. Rabat: Islamic Educational, Scientific and Cultural Organisation.

Husain, S. S., \& Ashraf, S. A. (1979). Crisis in Muslim Education. Jeddah: King Abdul Aziz University.

Hynes, J. (2006). The Politics of Religion: A Survey. London: Routledge.

Ibrahim, Y. R. (2009). Poltitical Islam: Affirmation of Negation (Malayalam Trans). In Jamat-e-Islami Vayanayum Prathinidanavum (pp. 70-87). Calicut: Islamic Publishing House.

Izetbegovic, A. A. (1984). Islam between East and West. Washington: American Trust Publications.

Kalin. (2008). Three Views of Science in the Islamic World.

Kazmi, Y. (2010). A Critical Analysis of the Influence of the Market on Education. Educational Awakening: Journal of Educational Sciences, 6 (1), 35-62.

Kazmi, Y. (2011). Being Muslim a Fact or a Challange.

Keddie, N. R. (1983). An Islamic Response to Imperialism. California: University of California Press.

Kurshid Ahmad \& Zafar Ishaq Ansari. (1979). Maulana Mawdudi: An Introduction to His Life and Thought. Leicester: The Islamic Foundation.

Mawdūdī, Abul. A’la. (1989). Let us be Muslims. London: Islamic Foundation.

Mawdūdi, Abul. A’la. (1988). Tafhīm al-Qurā’n (Vol. 1). (Z. I. Ansari, Trans.) London: Islamic Foundation.

Mawdūdī, Abul. A'la. (1976). The Role of Muslim Students in the ReConstruction of the Islamic World( Malayalam Trans.). Damascus: The Holy Quran Publishing House.

Muslim ibn al-Hajjaj al-Qushayri. (trans. 1999). Sahih Muslim. (A. H. Siddiqi, Trans.) Delhi, Adam Publishers. 
Qutb, Muhammad. (1977). The Role of Religion in Education. In al-Attas, Aims and objectives of Islamic education. Jeddah: King Abdul Aziz University.

Qutb, Sayyid. (2000). Social Justice in Islam. (H. Algar, Ed., \& J. B. Hardie, Trans.) New York: Islamic Publications International.

Rahman, F. (1982). Islam and Modernity: Transformation of an Intellectual Tradition. Chicago: The University of Chicago Press.

Siddiqi, Mesharudin. (1982). Modern Reformist Thought in the Muslim World. Islamabad: Islamic Research institute.

Tamimi \& Esposito. Edt. (2002). Islam and Secularism in the Middle East. London: C Hurst \& Co.

Tamimi, A. (n.d.). insight-info.com. Retrieved June 2006, from Insight.

Yusuf Ali, A. (2006). The Holy Qur'an: Text, Tanslation and Commentary. Kuala Lumpur: Islamic Book Trust. 